Portland State University

PDXScholar

$1-8-2016$

\title{
An Activity-related Land Use Mix Construct and Its Connection to Pedestrian Travel
}

Steven R. Gehrke

Portland State University

Follow this and additional works at: https://pdxscholar.library.pdx.edu/trec_seminar

Part of the Transportation Commons, Urban Studies Commons, and the Urban Studies and Planning Commons

Let us know how access to this document benefits you.

\section{Recommended Citation}

Gehrke, Steven R., "An Activity-related Land Use Mix Construct and Its Connection to Pedestrian Travel" (2016). TREC Friday Seminar Series. 22.

https://pdxscholar.library.pdx.edu/trec_seminar/22

This Book is brought to you for free and open access. It has been accepted for inclusion in TREC Friday Seminar Series by an authorized administrator of PDXScholar. Please contact us if we can make this document more accessible: pdxscholar@pdx.edu. 


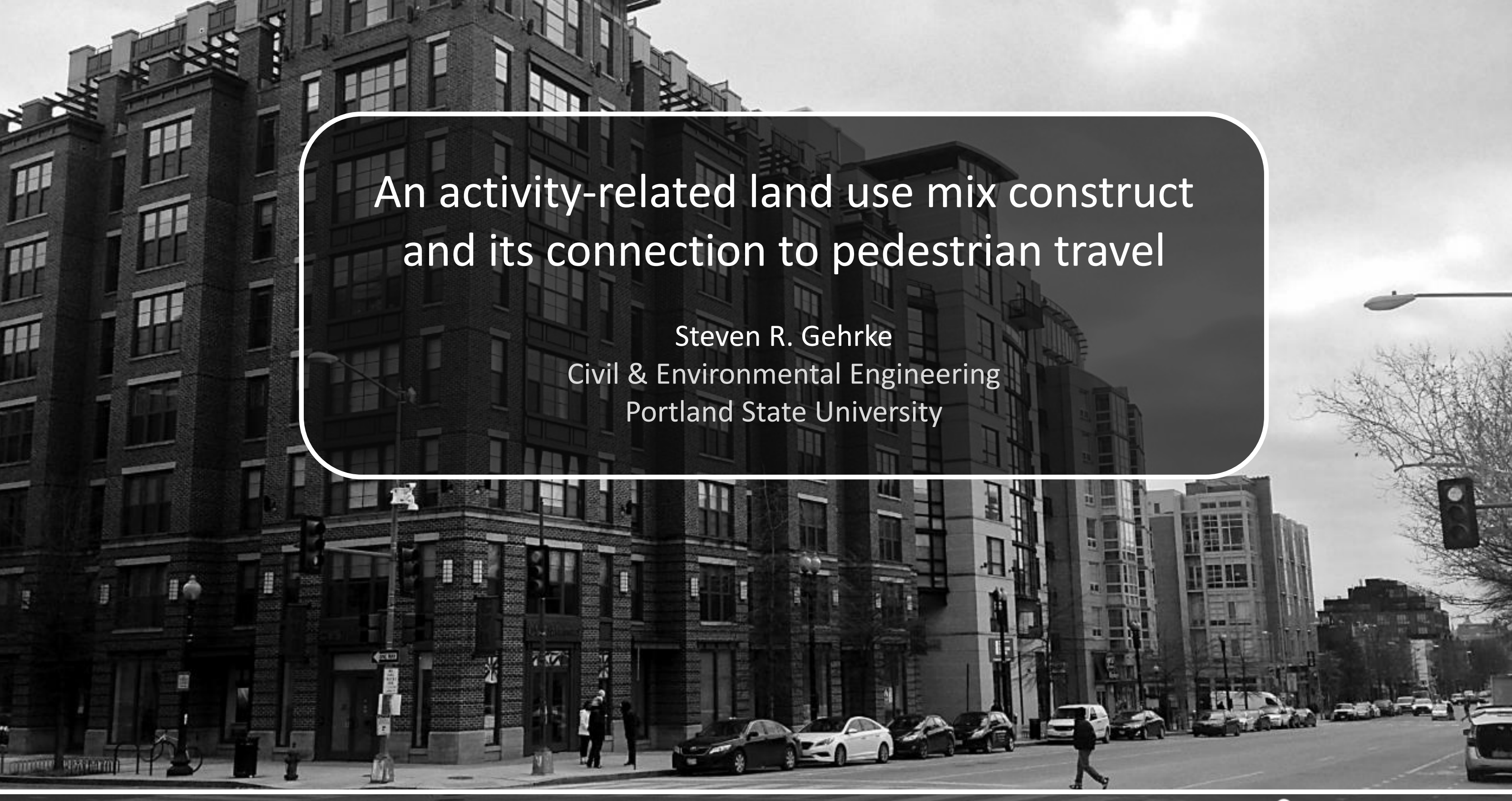




\section{Research context}

Sustained popularity toward investigating transportation-land use interactions

- Prospect to moderate travel behavior by physically altering our urban landscape

Increased adoption of policies focused on land use mixing

- Smart growth communities and mixed use developments

- Improve BE efficiencies increase local accessibility and encourage walking
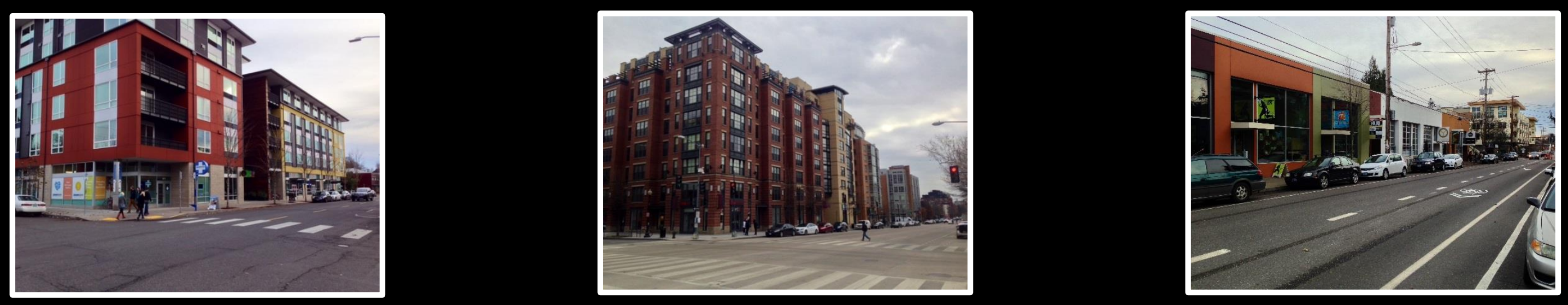


\section{Research interest}

Multidisciplinary interest

- Reduce auto-related travel behaviors, balance travel demand, promote tour complexity

- Promote urban revitalization, slow rural land consumption, increase visible interest

- Higher rates of physical activity, reduced vehicle emissions, mental health benefits

Remains a goal without an established set of indicators

- Variety of metrics evaluating effectiveness of programs or policies in relation to travel

- Misguidance of practice by adoption of measures with imperfect theoretical foundations 


\section{Land use mix measurement}

\section{Accessibility}

Ease of an individual to reach an opportunity from a location

\section{Theorized link to travel}

Reduced distance between locations increases feasibility of walking by diminishing competitive edge of faster modes

\section{Shortcomings}

- Only measures distance between two activity locations

- Provides summary calculation for only the origin

\section{Accessibility Measures}

- Distance-based

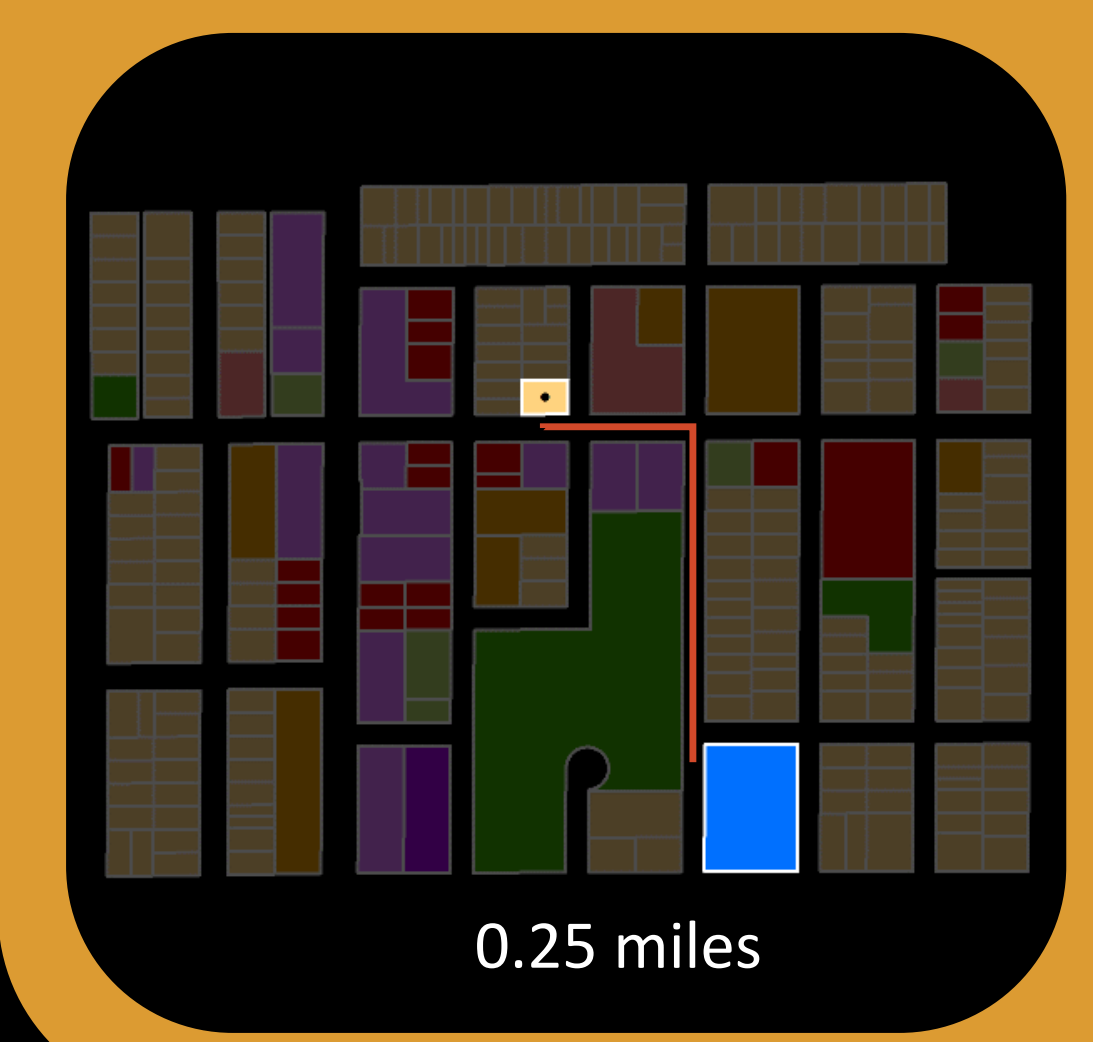




\section{Land use mix measurement}

\section{Intensity}

Count of locations or percent of area related to land use type

Theorized link to travel

Increased intensity of activity locations enhances practicality of walking to fulfill a variety of daily life activities

\section{Shortcomings}

- Inability to summarize intensity of multiple land use types

- Sensitive to chosen spatial extent for operationalization

\section{Intensity Measures}

- Count-based

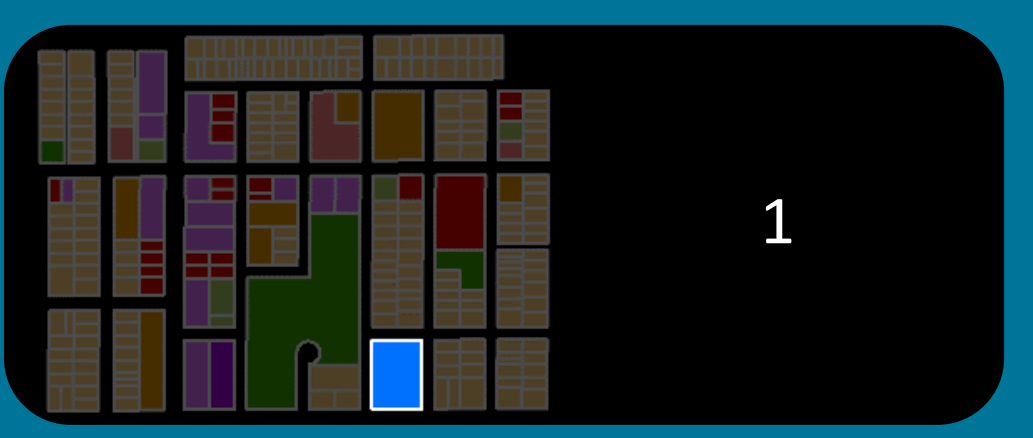

- Percent-based

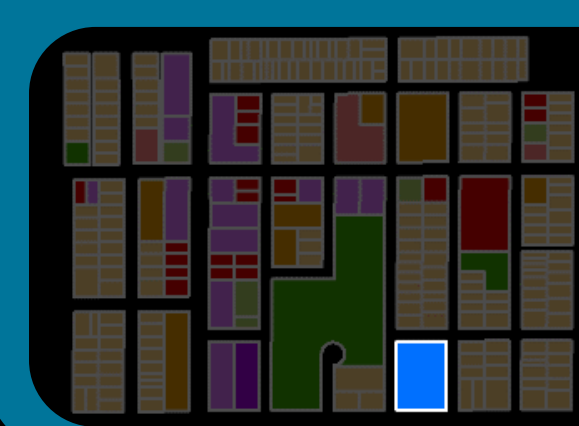




\section{Land use mix measurement}

\section{Pattern}

Level of integration among different land use types in an area

Theorized link to travel

Mix of residential and nonresidential land uses encourages internal walking trips in place of potential external auto trips

\section{Shortcomings}

- Entropy indices have perfect balance assumption

- Limited consideration of functional complementarity

- Concentration on non-spatial composition measures

- Variety in adoption of land use typologies

\section{Pattern Measures}

- Composition

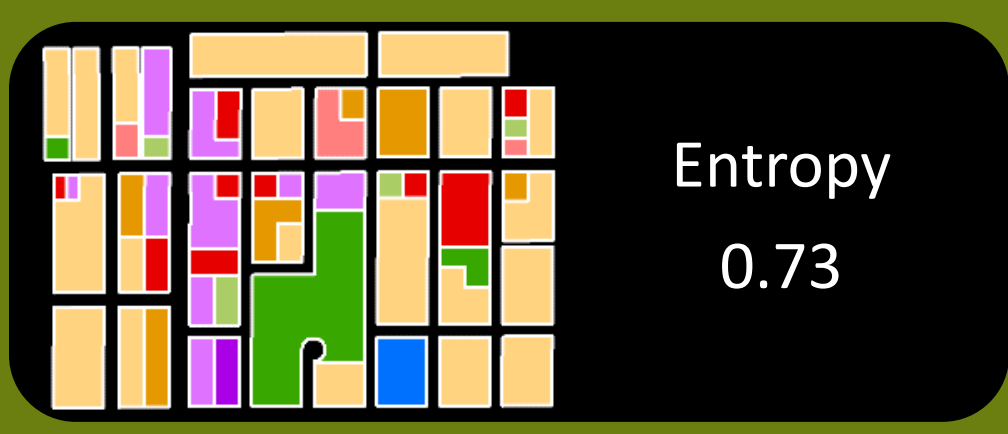

- Configuration

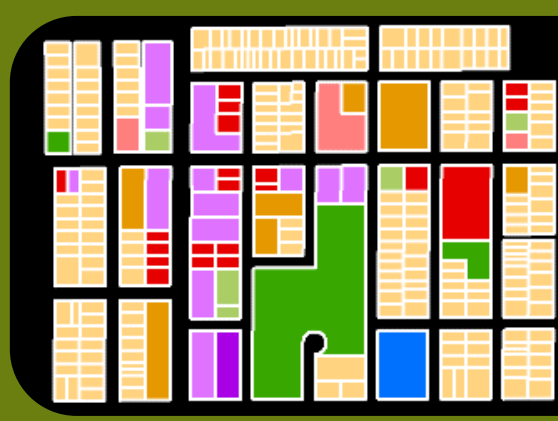




\section{Land use composition and configuration}

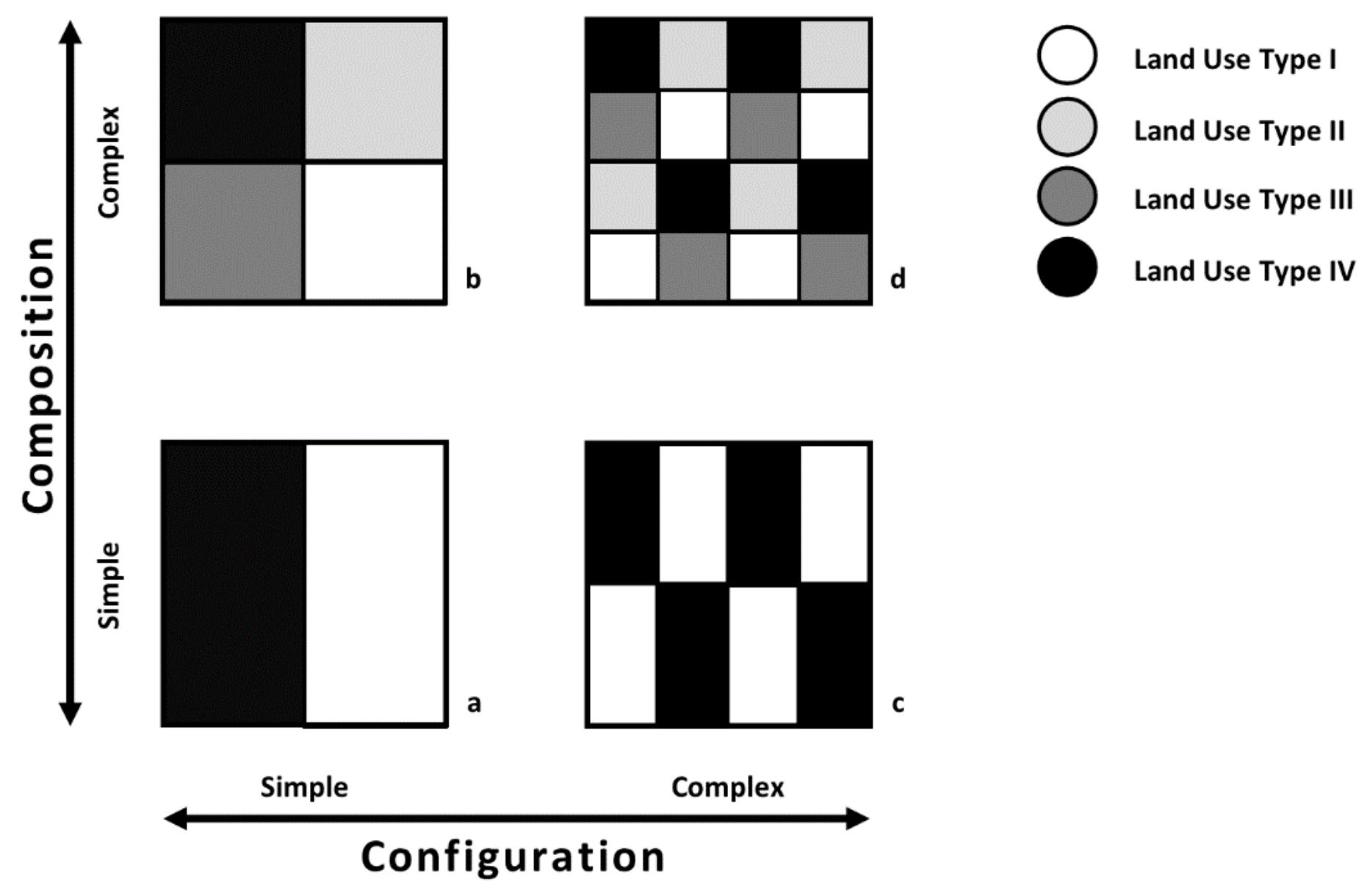




\section{Pattern in landscape ecology research}

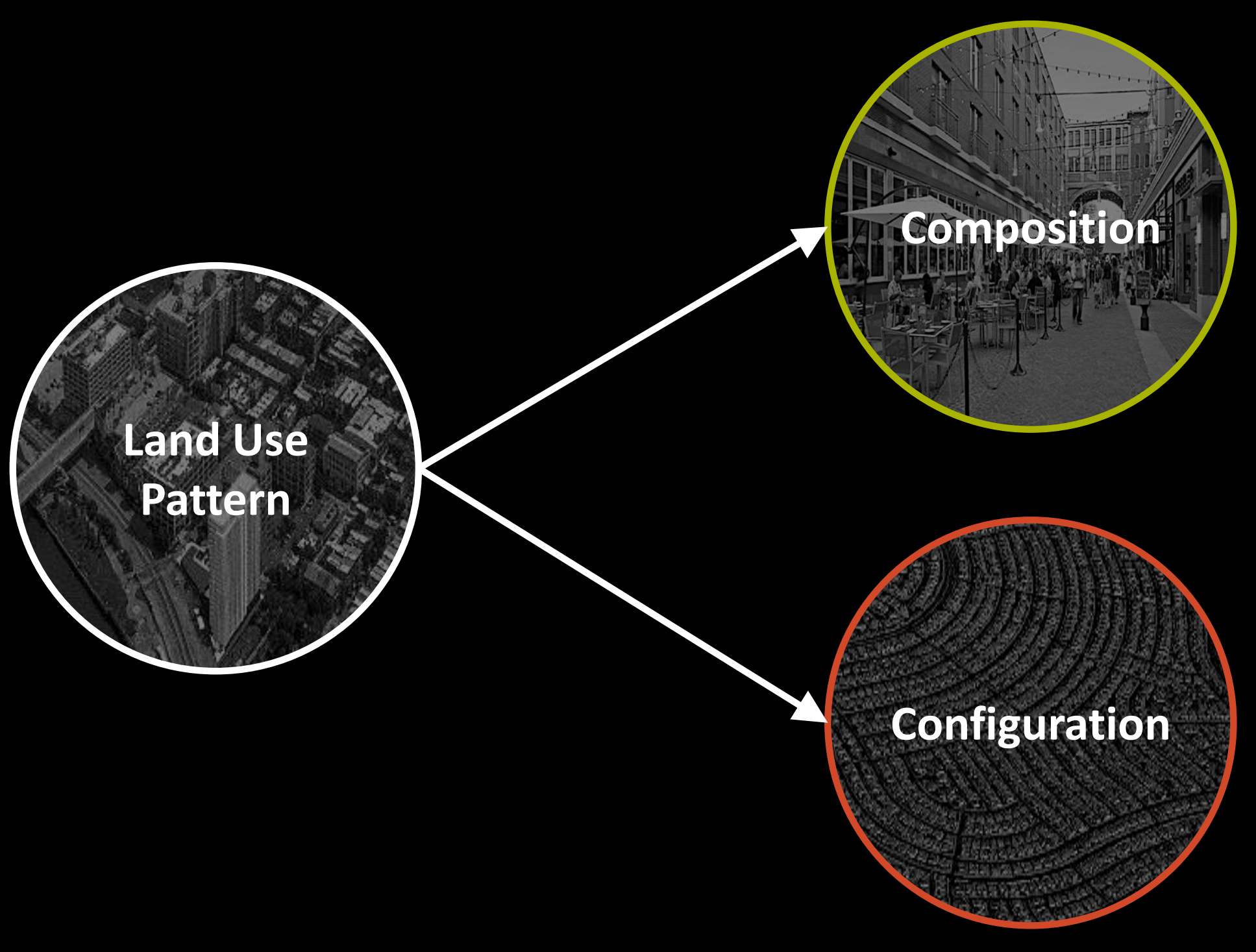

- Richness

- Proportion

- Diversity

- Evenness

- Patch Size / Shape

- Isolation / Proximity

- Contagion / Interspersion

- Connectivity 


\section{Study objectives}

1. Introduce land use mix measure reflecting construct's multidimensionality

- Quantify the composition, configuration, and complementarity of local land use types

- Explore the impact of geographic scale on land use mix measurement

2. Demonstrate connection between mix construct and pedestrian travel

- Examine impact of mix on trip-level walk mode choice and home-based walk frequency

- Compare effect of land use mix construct to effect of entropy and other BE measures 


\section{Study area $\&$ data sources}

\section{Land use}

- Parcel-level data from local jurisdictions

- Study area contained 904,398 parcels

- Disaggregated to 65,312,000 66-ft grid cells

- Additional data from secondary sources

- Density: 2010 US Census and 2011 LEHD

- Design: 2011 TIGER files

\section{Transportation}

- 2009-11 OR Household Travel and Activity Survey

- Info on 8,725 households, 14,264 adults, \& 64,060 trips

- Walking feasible ( $\leq 2$ miles) for 29,198 trips

- Walk mode chosen for $15 \%$ of trips $(n=4,344)$

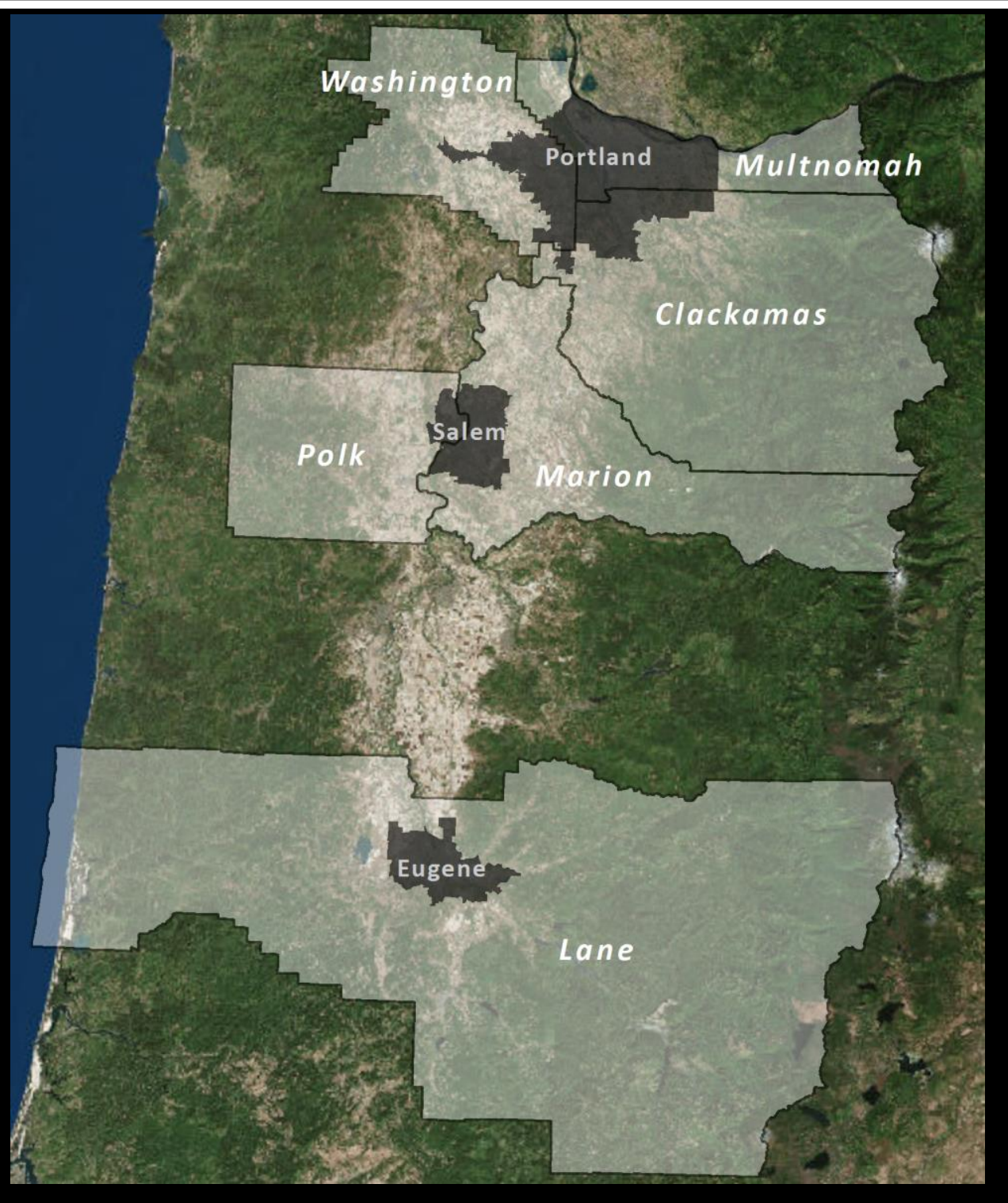




\section{Analytic plan}

\section{Land Use Mix Measurement}

- APA Land-based Classification Standards (Function)

- Operationalize indicators at artificial fixed grids

- 1.00-mile grid: 10,250 cells

- 0.50-mile grid: 40,820 cells

- 0.25 -mile grid: 163,280 cells

- Confirmatory Factor Analysis

- Assign predicted factor scores to grid cells

Connection to Pedestrian Travel

- Estimate impact of mix on walk mode and trip count

- Compare land use mix construct to entropy index and other BE determinants of walking behaviors

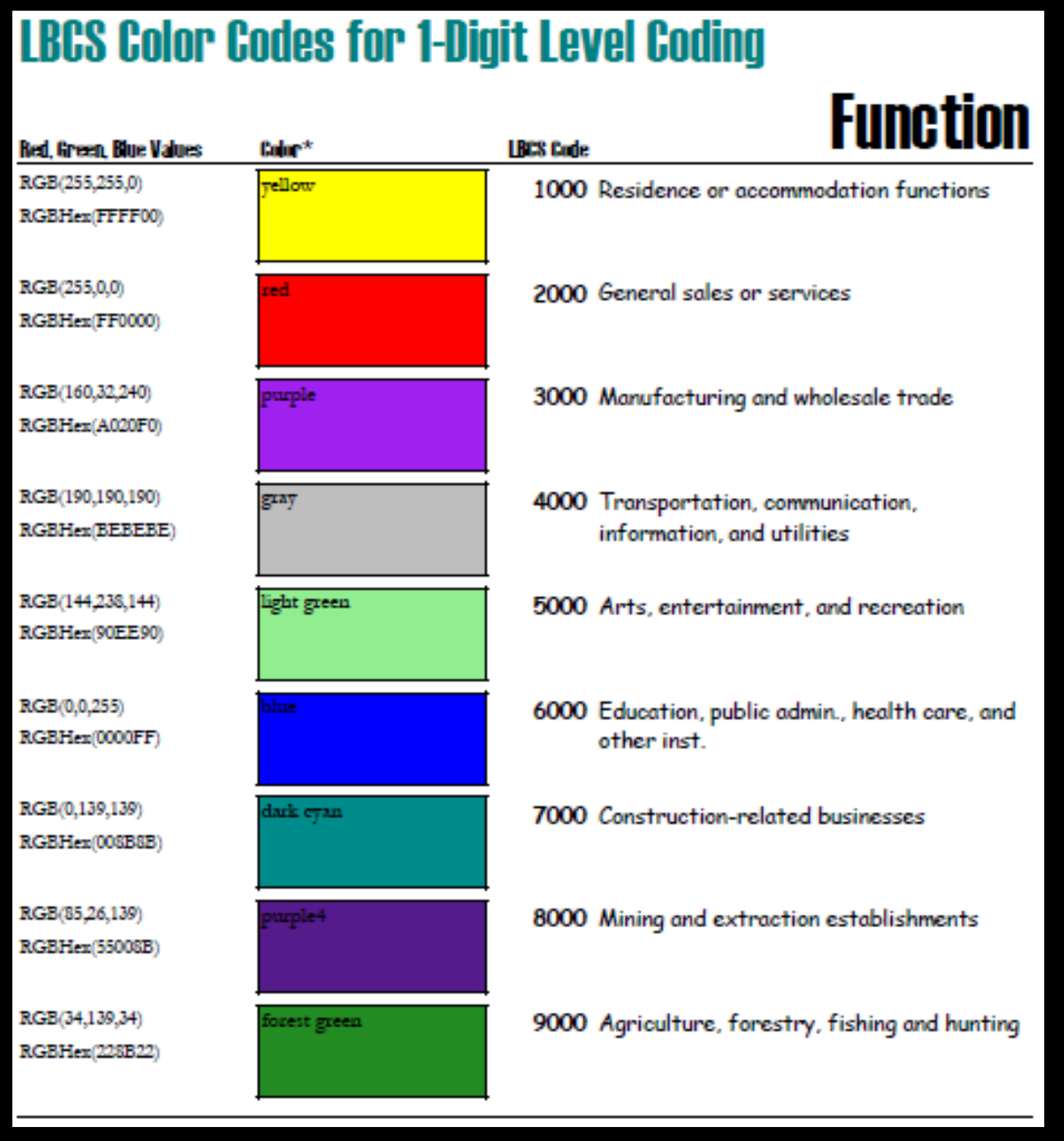




\section{Land Use Mix Measurement}
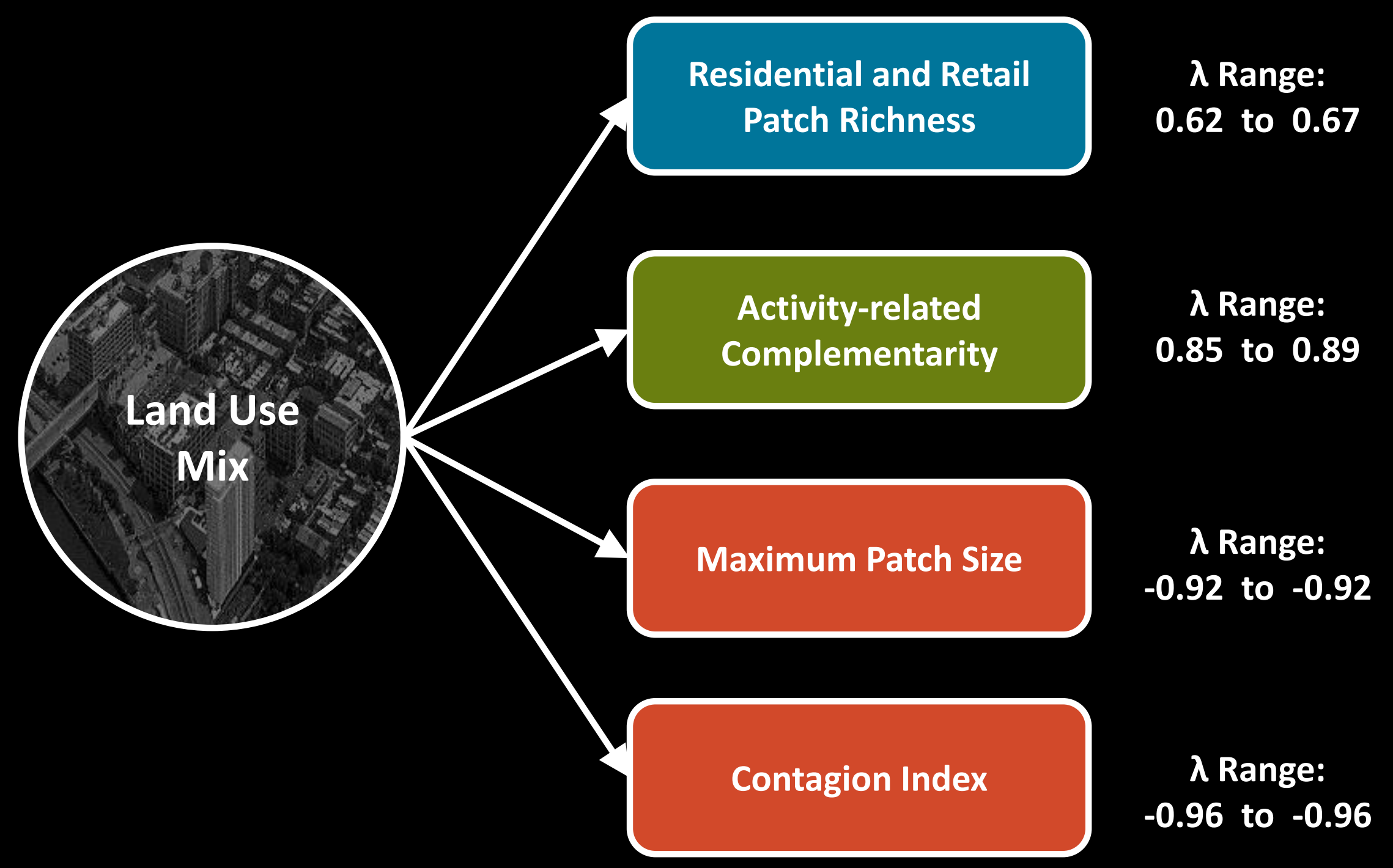

CFA Model Summaries

M1: Quarter-Mile Grids

CFI:

0.99

RMSEA:

0.02

M2: Half-Mile Grids

CFI:

0.99

RMSEA:

0.06

M3: One Mile Grids

CFI:

0.99

RMSEA:

0.09 


\section{Land use mix construct}

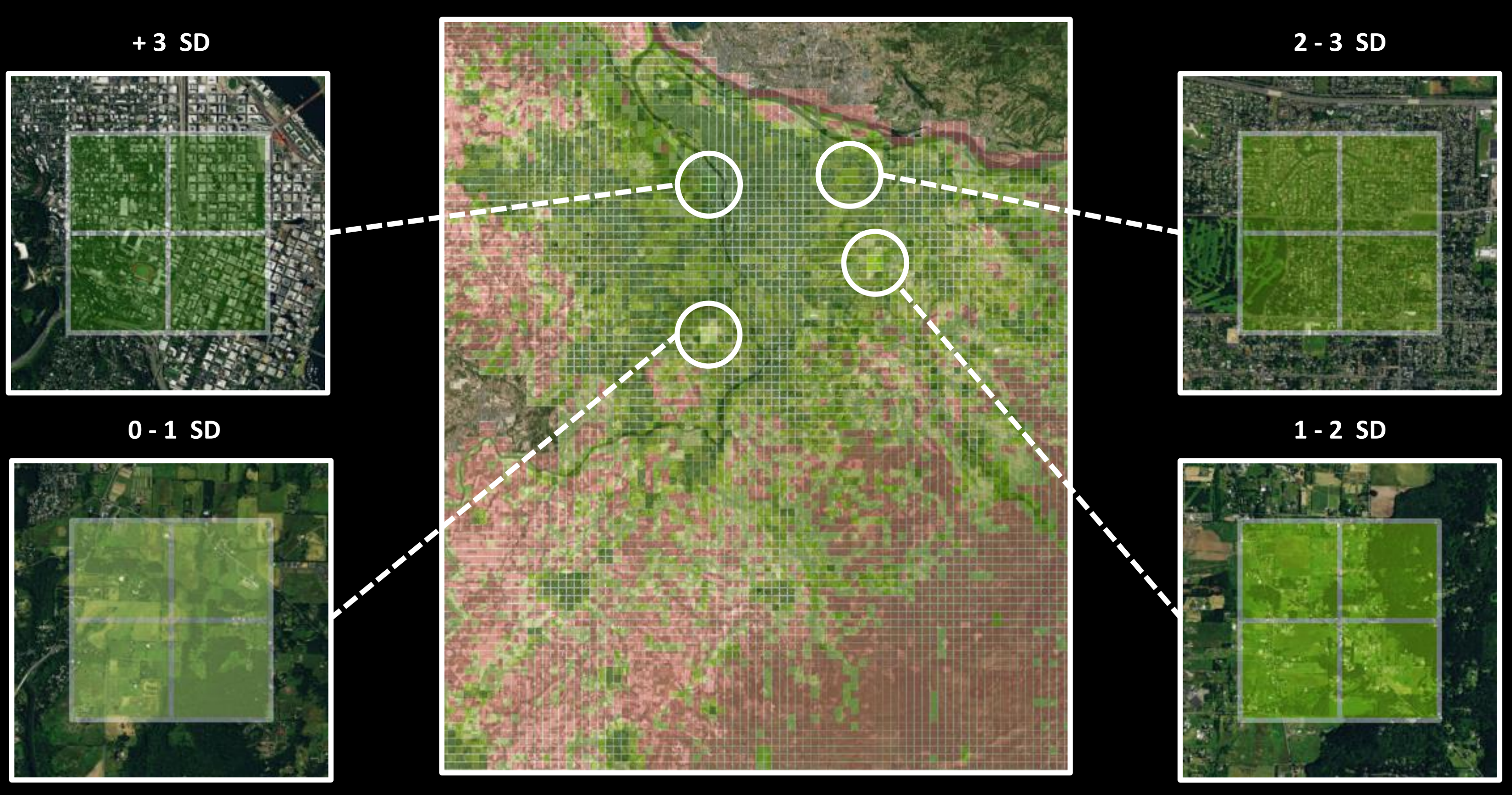




\section{Connection to Pedestrian Travel}

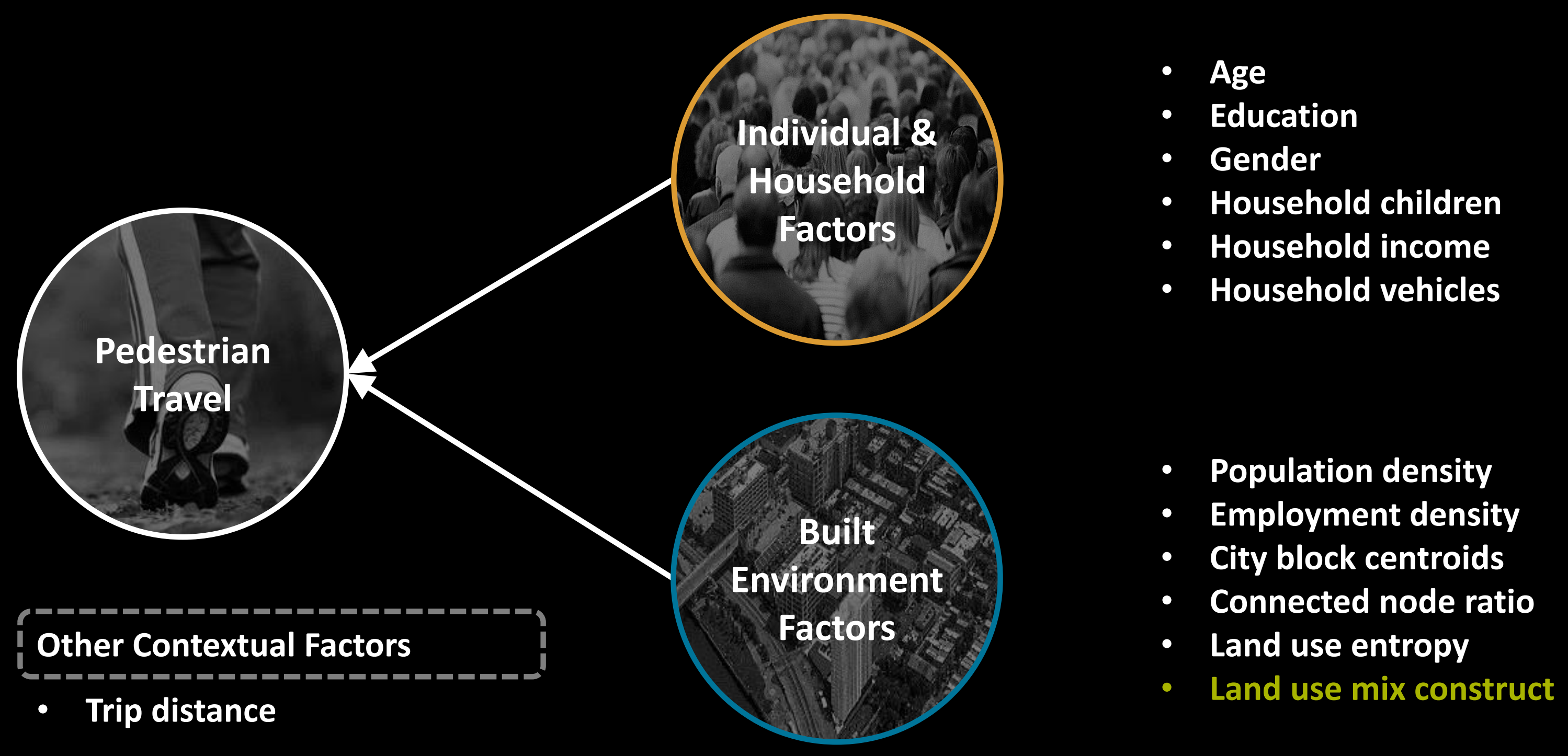




\section{Walk Mode Choice}
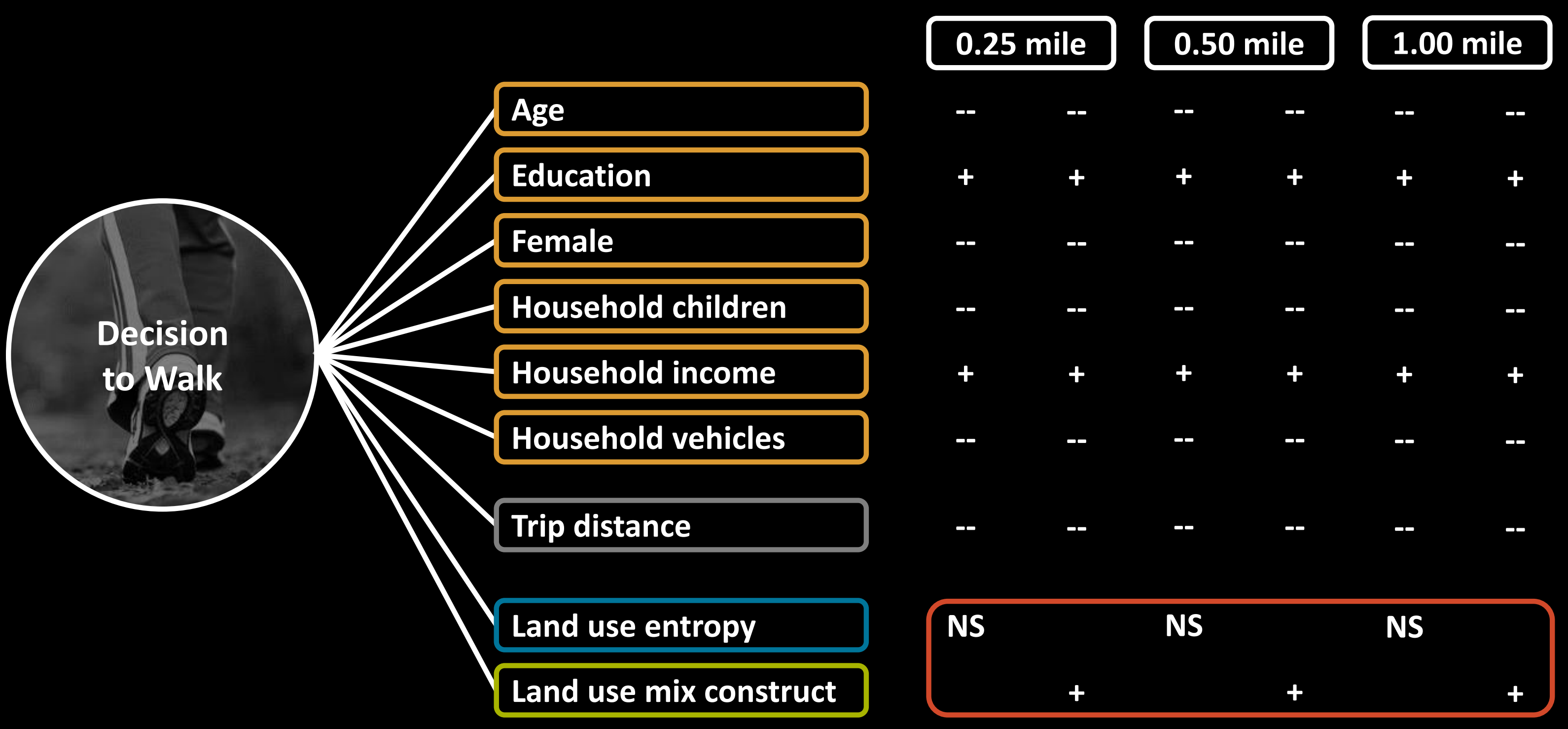


\section{Walk Trip Frequency}
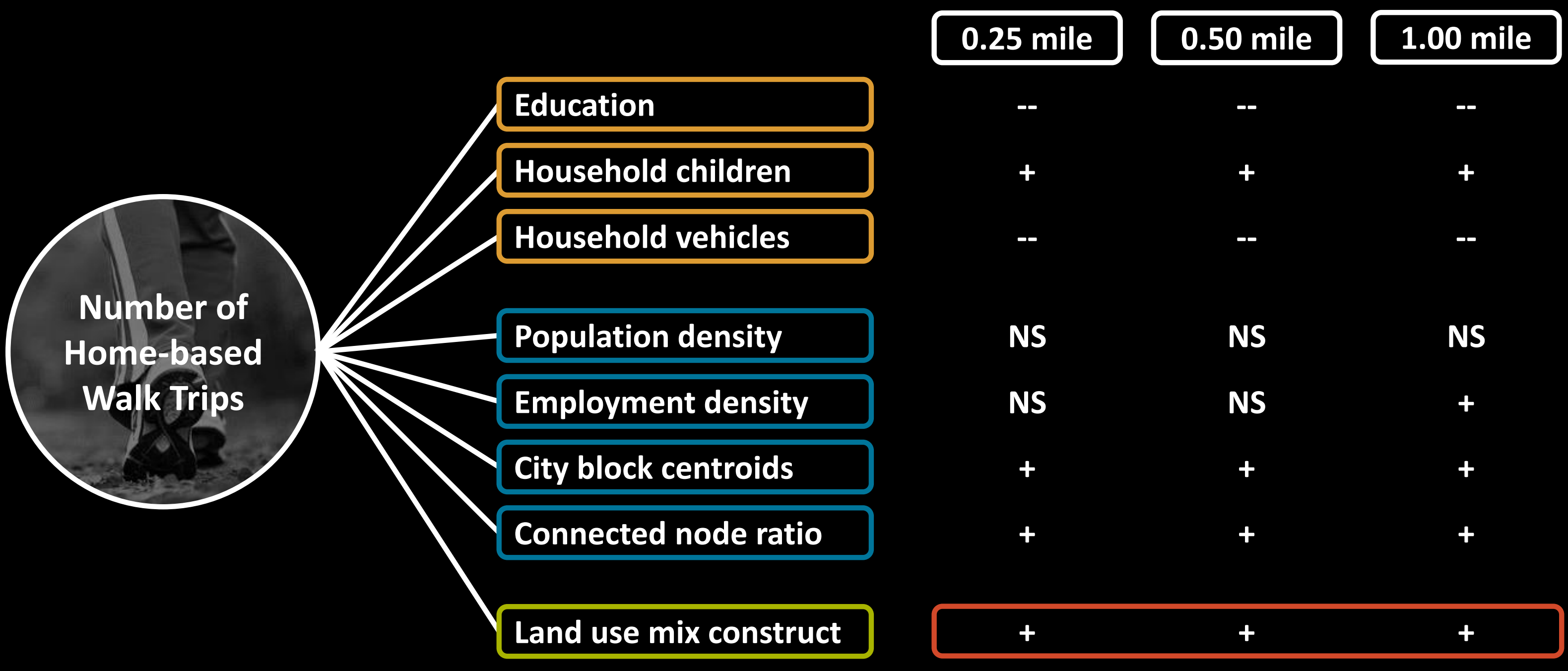

* Age, household income, and gender were not statistically significant 


\section{Conclusions}

\section{Study Findings}

- Improved land use mix measurement

- Multidimensional construct described by intensity, composition, and configuration

- Activity-related complementarity indicator moves beyond equal balance assumption

- Demonstrated link to pedestrian travel

- Construct was stronger predictor of decision to walk than entropy measure

- Construct was also significant predictor of home-based walk trip frequency

\section{Next Steps}

- SEM framework for retention of construct in measurement model

- Further attention to choice of geographic scale used to operationalize construct

- Transferability to states with weaker growth management policies 


\section{Bonus Slides}




\section{Activity-related Complementarity}

Pattern Measure of Land Use Composition

$$
A R C=1-\sum_{i=1}^{n}\left[P_{i} \cdot \frac{\left|P_{i}-F_{i}\right|}{1-F_{i}}\right]
$$

Where,

$P_{i}=$ Proportion of Land Use Type $i$

$F_{i}=$ Activity Factor for Land Use Type $i$

\begin{tabular}{lllllllll}
$\begin{array}{l}\text { Land Use } \\
\text { Type }\end{array}$ & $\begin{array}{l}\text { 1000: } \\
\text { Residence }\end{array}$ & $\begin{array}{l}\text { 2000: } \\
\text { Sales }\end{array}$ & $\begin{array}{l}\text { 3000: } \\
\text { Trade }\end{array}$ & $\begin{array}{l}\text { 4000: } \\
\text { Transport }\end{array}$ & $\begin{array}{l}\text { 5000: } \\
\text { Entertain }\end{array}$ & $\begin{array}{l}\text { 6000: } \\
\text { Education }\end{array}$ & $\begin{array}{l}\text { 7000: } \\
\text { Construct }\end{array}$ \\
\hline $\begin{array}{l}\text { Activity } \\
\text { Factor }\end{array}$ & 0.41 & 0.31 & 0.03 & 0.01 & 0.01 & 0.17 & $\begin{array}{l}\text { 8000: } \\
\text { Extraction }\end{array}$ & \begin{tabular}{l} 
Agriculture \\
\hline
\end{tabular} \\
\hline
\end{tabular}

